\title{
Literary Reputations in the Post-Literacy Era: The Image of a Writer in the Runet
}

\section{Boeva Galina}

Saint Petersburg State University of Industrial Technologies and Design,

St. Petersburg, Russia

g_boeva@rambler.ru

\begin{abstract}
The communication trend of the media discourse in the Runet, associated with the use of images of writers, is explored. The material used in this study includes Internet memes augmented with the images of classical writers and precedential quotations from their works. The theoretical basis is the concept of literary reputations (I. N. Rozanov). Transformations of literary reputations influenced by the technologies and values of the post-literacy era are analysed; new cultural meanings of the existence of literary concepts are revealed.
\end{abstract}

Keywords: literary reputation, writer, internet meme, participatory culture, post-literacy, communication, precedential text, creolised text

\section{Introduction}

The Internet is flooded with small speech genres [Bakhtin, 1996]: demotivators, memes, 'advices', humorous postcards, 'pies' and 'powders' (genres of network poetic quatrains), which are actively studied in the context of both genreology and communication [Shchurina, 2010; Nezhura, 2012; Shomova, 2018]. Their main properties are virality, the ability to replicate, communicative expansion, focus on humour and rapid turnover: they are often associated with the urgent issues of the day, but at the same time they broadcast basic stereotypes that go back to national culture - mainly its precedent phenomena [Karaulov, 2007, 216]. Meme, a word introduced in the 1970s by R. Dawkins [Dawkins, 1993], is difficult to identify, especially when it comes to its existence on the Internet: this is both a kind of precedent phenomena' [Shchurina, 2010, 84], and a kind of creolized text [Sorokin, Tarasov, 1990, 180-181] using the resources of precedent: 'A meme has a cultural connotation that enables the addressee to identify the precedent phenomenon' [Shchurina, 2012, 163]. Such a fragility of the concept is explained 
by the fact that the meme appears only in the perceiving consciousness, this phenomenon is entirely receptive.

As a phenomenon of verbal communication, witty aphoristic phrases were 'invented' long before the Internet era: they were an essential condition for communication of the high society (recall the 'phrases of portable properties' quoted in living rooms - 'les mots', in the invention of which one of the heroes of 'War and Peace', Diplomat Bilibin, succeeded). However, only Internet technologies have allowed them to become a truly massive phenomenon. Emerging in various Internet communities (social networks, chats, forums), Internet memes often go beyond the global network and are 'prescribed' in the language of everyday life, become the basis for advertising, and penetrate the media.

In the Runet, there are many so-called meme generators - on various sites, the user is asked to enter his own captions into the finished picture. There is even a Memepedia website dedicated exclusively to the viral content, with its own Memotek, an encyclopedia of popular memes classified by headings, years and the alphabet. Obviously, we are faced with a part of a 'culture of participation' that is powerfully asserting itself in the network (G. Jackins [Jenkins, 1992]). By adding to our cultural roles of reader, listener and viewer a new one, a user, we have become not only consumers, but also producers of texts [Zvereva, 2012, 8].

If we look for cultural analogies to the ubiquitous anonymous Internet memes, then a parallel arises with the carnival laughter culture of the Middle Ages [Bakhtin, 1990, 17] with its liberating laughter, opposed to the seriousness of the official culture. The abundance of the 'indecent' amonst Internet products stemming from the relative moral and ethical uncensoredness of the network space, can also, in accordance with the works of A. M. Panchenko, D. S. Likhachev, B. A. Uspensky, be considered in the context of folk laughter culture as curse words associated with the material-bodily bottom. In the modern postmodern discourse the binarity of the Russian culture noted by Yu. M. Lotman becomes irrelevant [Lotman, 1997, 596] as the border between 'high' and 'low' is blurred, and the mass culture compromised in the national tradition, associated with everyday practices, broadcasts not only kitsch, but also important value meanings [Knabe, 1989].

Since in Russia a sacred attitude to the word persisted for quite a long time and writers had a special status of rulers of thoughts and prophets, their 
position in the pantheon of the greats was legitimised by the institutions of the entire previous culture, whose power is appropriated by an anonymous Internet author [Bourdieu, 2000]. Despite the fact that the literary centricity of the Russian culture has remained in the past and literature is no longer synonymous with culture, the writers included in the 'literature canon' continue to be among the popular 'heroes' of Internet creativity. Quite often, it is the sacred figures of writers from the literature canon that become 'victims' of the laughter carnival outrage of the Runet.

Let me explain the concept of 'literature canon'. It does not have a strict literary significance and is distinguished by its controversial nature [Zemskov, 1999; Megrelishvili, 2013]; we can talk about at least three canons ('actual', 'school' and 'fashionable' [Dubin, 2010, 69-70]), touch upon aspects of their historical variability, 'social targeting', communication with literary hierarchies and national mythology. M. Yampolsky defines the 'canonical text' quite capaciously and concisely: 'it is... a text that ceases to belong entirely to the author and whose meaning acquires a certain ontological character' [Yampolsky, 1998, 219]. I will understand by the literature canon 'a set of texts recognised as ideal in the system... of the national cultural tradition' [Guskov, 2016, 176]. Entering the canon, the author acquires a biography, becomes mythologized, just as a saint is canonised [Berg, 2000]. In the Russian national culture, for example, this path was most clearly followed by Pushkin [Reitblat, 2001]. The concepts of 'classical author and classic' cannot be called purely scientific concepts, they are discovered only in the field of reception [Zenkin, 2009, 281-282].

Finally, it is necessary to introduce another concept related to the perception of the images of writers by Internet users: the stereotypes that guide the creators of memes are based on the theory of literary reputation. This concept was introduced by I. N. Rozanov [1928] a century ago and further developed by a number of researchers [Mashkovtseva, 2012]. Based on the ideas expressed by them, I will offer my own understanding of the literary reputation: this is a complex, varying with time, public image of a writer which is formed as a general picture of the reception of his work by all participants in the literary process - critics, contemporary writers and readers.

The purpose of this study is to trace what constituents of writers' literary reputations are relevant to users and what transformations they undergo under the influence of technologies and values of the post-literacy era on the basis of Internet memes in the openly accessible resources of the Runet; 
what new cultural meanings of the existence of literary concepts are revealed. Let us turn to various types of Internet memes that exploit the images of writers - we will be interested in both text memes (using quotes and plot collisions from key texts of classical literature), and picture memes (less often), and creolized texts - 'picture + accompanying text'... We will have to leave aside video memes, which go back mainly to screen adaptations of classic literary works (often the mass consciousness equates a text and a film). The subject of my interest will be the figures of the Russian literature canon, and therefore I will not focus on memes referring to foreign literature (for example, popular 'advices' with the image of W. Wolfe - the personification of a 'philological maiden') which has its own canon [Bloom, 2017].

I will comment on another large plot layer of Internet memes which will have to be ignored now - those associated with fictitious love relationships between same-sex characters in literary works and their authors (for example, between Onegin and Lensky, Pushkin and Gogol). Such love stories called 'slash' [Prasolova, 2008] should also be viewed in the context of the 'culture of participation' within fanfiction, i.e. fan literature. Slash memes telling about the relationship of male characters in the canon are proof of the laughable, carnival nature, perversity of small speech Internet genres in relation to traditional values.

\subsection{The core of the canon: Pushkin and Gogol}

A large number of Internet memes of the 'literary origin' are either puns or play on the sound shell of the exploited literary content. Here we are dealing only with external attachment to literary material. The situation is similar with the parodies in the description of Yu. N. Tynyanov who distinguishes between parody 'debunking' the original and exposing the technique, and parody only using an 'alien form' as a popular matrix and emphasising the contrast between 'low' and 'high' [Tynyanov, 1977, 290]. An example of a pun meme for which the literary form is indifferent can be a photo of a label from a grocery store in which the consonance is played out and the name of the product and the producing country is contaminated: 'Carrots' Unwashed Russia': / Garlic of slaves and onions of masters, / And blue eggplants, / And other miscellaneous root crops ${ }^{*}$

* Hereinafter, the cited Internet memes are in italics, with the spelling and punctuation of anonymous authors preserved. 
Here are some more examples of such 'frivolous' literary memes, 're-singing' a quotation or the name of a writer and not suggesting 'immersion' in the pre-text: 'Laughing all the way to the bank' (a picture with Raskolnikov); 'Hello, is this Griboyedov? I'm a vegan too' (picture of a penguin talking on a cell phone); 'Bitter - Sweet' (portrait of M. Gorky as an advertisement for a pie in KFC); 'Hook on the left Hook on the right Block' (photograph by A. Blok between two reproductions of a portrait by the German artist J. G. Hook); 'Leo Tolstoy was not a fat lion' (images, respectively, of the writer and the lion).

Further, I will not distinguish between puns and memes that unite the author and the recipient on the basis of a common, at least superficial knowledge of the subject. I will confine myself to demonstrating one example of the difference between them: the first one uses the tautological consonance technique and addresses the entire body of the classics, without delving into its characteristics: 'Russian classical literature - all in one class' (against the background of a typical graduation photograph of the class with portraits of schoolchildren in round frames - instead of them the classics from the school curriculum from Pushkin to Gorky); the second one - a text without a picture, in black and white: 'All Russian literature is built entirely on suffering. Either the author or the reader suffers' (variant: 'Everything is very bad. Now let's talk about this in more detail on 700 pages'). Obviously, in the latter case, the author of the message and its addressee are supposed to have a common knowledge of the psychologism of the Russian classic novel and at the same time there is an ironic allusion to its many pages and a reference to the concept of 'suffering' that is important for Dostoevsky. There is another Internet picture on the same topic, ironically shuffling the 'ingredients' of an archaic picture of the world: on a turtle labeled 'suffering' there is 'Russian literature' in the form of three elephants - 'new man', 'extra man' and 'little man'... In one of the blogs, I even found a meme with the projections of literary reputations on the fragrances: on each bottle, along with the image of the writers, there is an annotation that plays on Lermontov's hussars, Pushkin's revelry, Yesenin's peasantry, Chekhov's medical education, Mayakovsky's love for Lilya Brik.

The idea of an Internet user about the Russian literary canon is reflected, for example, in the following meme: 'So. all right. You didn't listen to me, so let them now explain to you what the difference between 'dress somebody' and 'put on' is' (option: 'You have three mistakes in one word') - Pushkin 
(in the centre), Gogol, Tolstoy, Dostoevsky and Chekhov are walking aggressively and proactively.

I consider those memes whose authors manage to reflect the idea of the literary reputation or the artistic world of the writer in an elegant, artistic form, with the help of a pun or consonance, to be especially successful as, for example, in this: 'Dovlatte: Coffee with the taste of yesterday's bitterness, overshadowing yesterday's shame'.

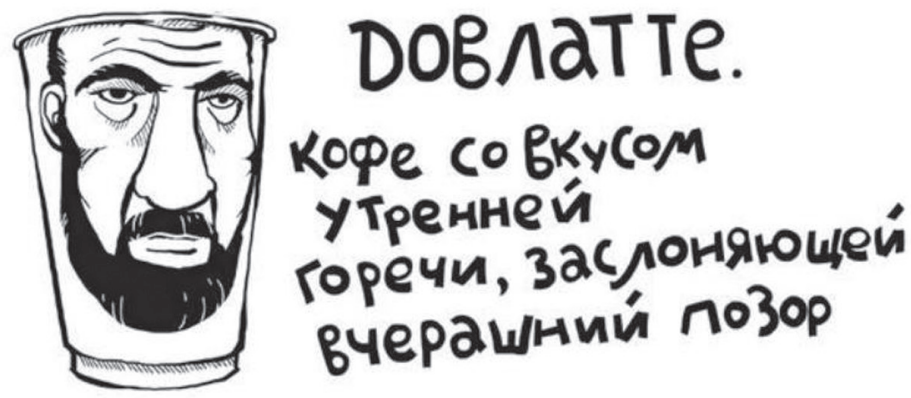

An indispensable condition for the successful perception of a meme dedicated to writers is cultural presupposition: acquaintance with the writer's work and biography in the scope of the school curriculum. For example, this one presupposes knowledge of the biographies of Russian poets and writers who, in a carnival spirit, are discredited as 'untrue saints': 'Literature teachers at school force 14-year-old children to analyse and understand the poems of adult drunks who committed suicide'. Or here's a meme quest: 'Our heroes (Dostoevsky, Mayakovsky, Yesenin) have lost their favourite items on the way. Help them. Give everyone the item they need. An axe, a pistol, a bottle... '

As you might expect, the most popular hero of literary memes is Pushkin, who is at the very core of the national canon. His central position is played up even on the meta-level: 'Pushkin is our meme' (next to the graphic self-portrait of the classic). Or like this: 'Sonny, have you done your homework? - No, I haven't begun it yet. - Who are you waiting for? Pushkin will do? - Why do I have to do that '***! I have already died' (the last remark belongs to the poet himself). Text: 'Chukchi is not a writer, Chukchi is a reader!' - accompanied, of course, by the image of Pushkin personifying the writer as such. 'No! Give me only a mug!' - We see a classic refusing an offer to drink (a reference both to a Soviet poster promoting sobriety and Pushkin's lines 'Let's drown our 
grief in drink; where is the mug?). Pushkin turns out to be a mythologised character, the precedent of which is truly inexhaustible. Here's how, for example, one of the latest network memo viruses 'Natasha and the cats' has been rethought: many Pushkins wake up 'Natasha' (wife?) anxiously: 'Natasha, get up, we have finished the Little Tragedies', 'Eugene Onegin' has even been finished,' 'Finished, honestly', 'We've finished everything'.

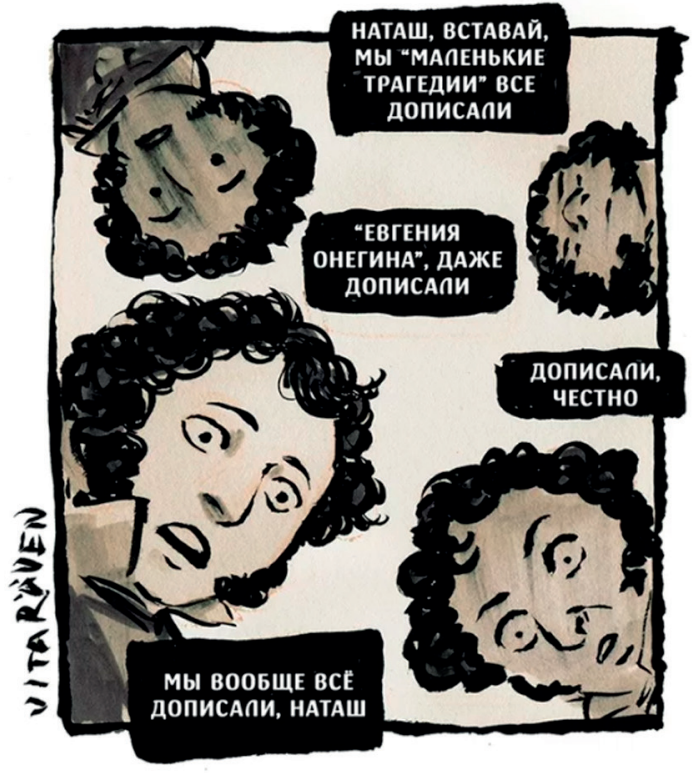

In most Internet memes about Pushkin, we will find references to the textbook version of his biography refracted by the mass consciousness that reduce the image of the classic (all of them are accompanied by wellknown images of the poet - a portrait by O. Kiprensky, V. Tropinin, etc.): 'A gambler, a womanizer, a duelist, African roots'; 'The first Russian rapper is not Timati. The first Russian rapper was A. S. Pushkin. He rhymed well, had African roots and died in a shootout'. In some memes, only one of the features of this stereotypical set is exploited, for example, a poet's duel, or his family life (a portrait of a poet and a text using two emoji-hearts 'Love is... Why did you say about my wife, ghoul, let's go out, Natasha, don't bother, I myself), or his 'Don Juan list': 'Women accuse Pushkin' - the text is accompanied by a graphic image of the contrite figure of the poet surrounded by women, 
angrily making claims on him. Obviously, here the reputation of a classic becomes a reason for a topical statement about harassment that generates information storms in the media and the Internet. Such relevant comments can be referred to a fashionable singer ('Remember Pushkin's poems! Remember all the songs of Face [modern rapper - GB] by heart!') or to a cult film. The meme with a frame from the film 'Pulp Fiction' by K. Tarantino is quite noteworthy: 'Come on, tell me about Pushkin again! You disgrace Pushkin. Let me remind you that in the film in this scene, one of the main characters, Bandit Jules, before killing a man, quotes an excerpt from the sermons of the prophet Ezekiel as the replacement of Scripture with the name of Pushkin suggests the perception of the latter as a sacred figure equivalent to a saint or a prophet.

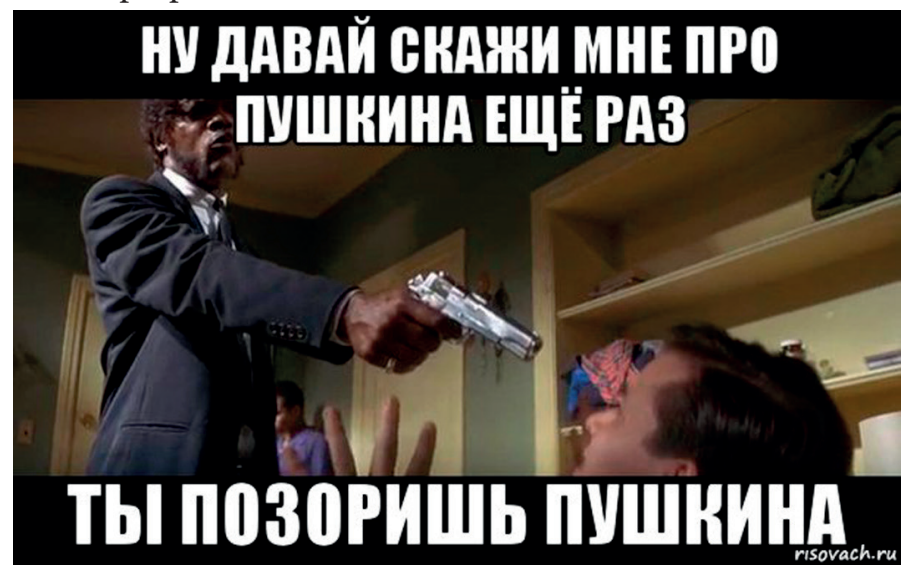

Since the Internet user is predominantly audio and visual, there are many overlaps between the images of literary classics and the heroes of popular films in memes. For example, Russian writers and poets are portrayed as the 'unstoppables' from the 2010 film of the same name (directed by S. Stallone), an American action movie featuring the most famous actors of the 1980s and 90s playing a group of elite mercenaries. And the plot of another meme is the projection of two bandits from the already mentioned 'Pulp Fiction' onto the main 'heroes' of the literary canon: Pushkin and Gogol point pistols at the viewer with the words: 'Have you read the Inspector General and Dead Souls? If not, go and read ${ }^{* * *}$. It would be more logical to demand reading one of Pushkin's and one of Gogol's - and here the question arises: did the anonymous Internet author know that Pushkin is defending another person 's copyright? 


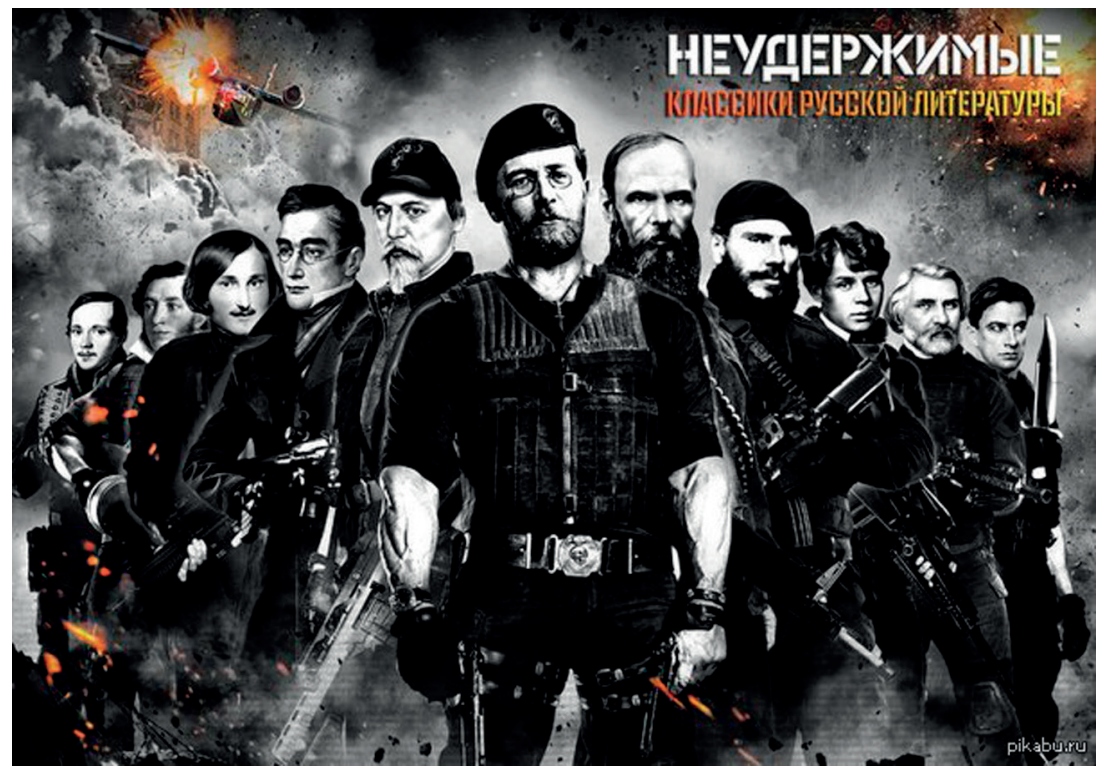

It is natural that the second most important figure in literary Internet memes is not Lermontov (only a few memes will tell us only about his Scottish origin and love for cards), but Gogol, who rivals Pushkin for popular fame (we cannot help recalling V. Belinsky's position about two directions of Russian literature - 'Pushkin' and 'Gogol'). Moreover, as it has repeatedly happened in recent decades [Kaspe, 2009], the film series 'Gogol' (directed by E. Baranov, 2017-2019), recently released on film distribution and on the screen and reflected in the memo creative work, added fame to the writer: 'You don't have to read Gogol, if you can go to the cinema to see him.' However, some memes, defending literary centrism, broadcast a critical attitude towards the series: 'Gogol of a healthy person (portrait of the writer by F. Moller) / Gogol of a smoker (portrait of an actor playing a writer in the series)' (option: the same images with the captions 'Good Gogol / Bad Gogol ').

The most 'memogenic' fact of the life and work of the writer is the burning of the second volume of Dead Souls by him: 'I have written you - I'll burn you' (both an appeal to the fact of the biography and a precedent phrase from 'Taras Bulba'); 'What if Gogol burned the second volume of Dead Souls because he wrote in the Latin layout and noticed it only in the last chapter?'; 'Your book will not be criticized if...' (plus a picture of a flame); 'Gogol to Bul- 
gakov: Misha, today we will groove (here we see wordplay: Russian words meaning 'groove' and 'light it up' have the same base). Don't you like the second part again?' (Gogol - to M. Bulgakov, the author of the famous Wolandian phrase 'Manuscripts do not burn') and even 'The film will be released in 4 parts, but the fourth will be burned.' It is noteworthy that Internet authors play up in their work such facts as the writer's love for macaroni and cheese and the mysterious circumstances of his death ('Guys, stop joking: you have pampered yourselves quite enough, it 's high time to open it already'), but completely ignore such components of his reputation as inclination to mysticism, preaching or disagreements with contemporaries due to his scandalously famous letters to friends, etc. - all this, apparently, remains 'overboard' of the school curriculum and cannot become a reliable basis for memes that rely on recognition or general availability.

\section{2.... and others}

It is not known whether the fact of early Dostoevsky's belonging to the 'Gogol' direction of Russian literature was known to the author of the following meme: 'I have read a lot of literature, but I think that only Gogol really 'grooved' ('lit it up') ' - the caption to the portrait of the writer by V. Perov. By the way, it is his most widespread image which has served as the basis for a large number of Internet memes - both biographical, and quote and plot ones. Among the latter, the leading ones are those referring to 'Crime and Punishment' - a work that is included in the 'school canon' and is wittily parodied by plot as follows: 'The cat shit in the shoes... Perhaps I will not scold him, but only hint that I suspect him. I will keep it in nervous tension until the cat repents.' 'Would you like some sweet oranges? Do you want long stories out loud? Do you want me to kill the neighbours that interfere with your sleep?' - a quote from the song of the singer Zemfira is accompanied by a picture of Raskolnikov. There is also a general idea of the writer's reputation: 'Dostoevsky in my head prevents me from being happy' (a picture with a silhouette of a child's head inside which there is a portrait of the writer). It is Dostoevsky with his idea of suffering who personifies all Russian literature in the following meme: 'English literature: I will die for a moral duty; French literature: I will die for love; German literature: I will die for greatness; Russian literature: I will die' (the same Perov portrait of the writer is placed here). 


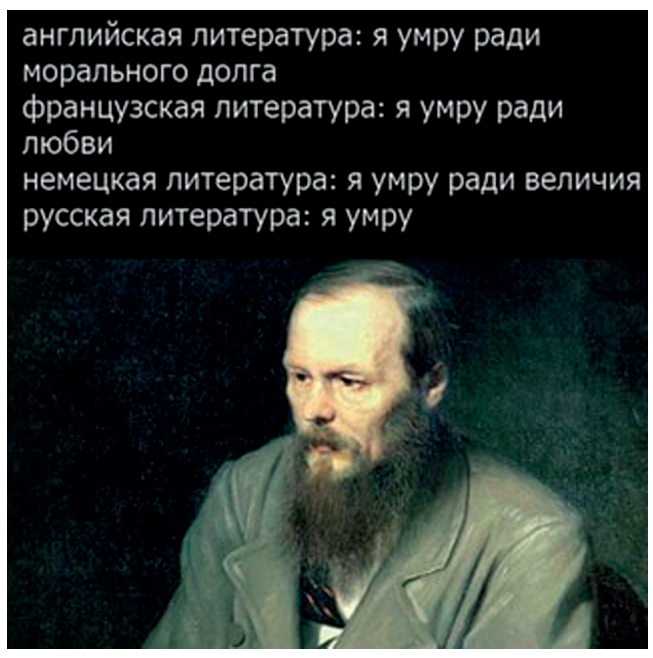

The poets from the literary canon of the twentieth century also seem to be 'gloomy' to the mememakers: 'Depression does not come alone: it brings Mayakovsky, Yesenin and Brodsky with it'. It seems that Russian literature opens up to the mass consciousness as extremely pessimistic, attuning to suffering and pain, and not encouraging or healing... And heroes do not always teach light or kind things, as it is presented in an ironic meme (in the spirit of G. Oster's 'bad advice') showing a stack of books with the following titles: 'Chatsky (How to ruin a party), Onegin (100 ways to lose friends), Raskolnikov (Sociopathy for dummies), Bazarov (We expel guests [? - G. B.]), Pechorin (How to be ${ }^{* * *}$ [unprintable word denoting a bad person - GB]).

Leo Tolstoy is famous among the mememakers primarily as the author of the epic 'War and Peace', which, apparently, since their school days have amazed them with an overwhelming volume - this is what most of the 'Tolstoy' memes are about: for example, depicting a thick and thin book with appropriate inscriptions: 'War and Peace' / 'War and Peace' without a description of the oak'; 'Jesus knew how to turn water into wine, and I turn it into War and Peace (tweet on behalf of Leo Tolstoy)'; four squares: 'Air magician, fire magician, earth magician, Leo Tolstoy [the meaning implied is 'water'-GB]'; 'Rewrite me in full' (the words of Tolstoy who is strictly looking at the addressee)', etc. It is obvious that the format of the epic novel is irrelevant to modern mass consciousness, and other works of Tolstoy are less rooted in the 'school canon'. The author of the 90-volume collected works 
was awarded the 'panegyric' only in comparison with one of his namesake writers: 'In words you are Leo Tolstoy, but in practice - Alexei' (attached portrait of Alexei Tolstoy).

Let us recall the meme 'The Expendables' which depicts the Russian classics in the form of military mercenaries - in fact, it represents the entire literary pantheon of the 19th century: Griboyedov, Pushkin, Lermontov, Gogol, Turgenev, Dostoevsky, Tolstoy, Nekrasov, Chekhov. It is noteworthy that we will not find Goncharov here, the author of Oblomov, who is traditionally 'squeezed out' in the school curriculum by his more 'successful' competitors - Dostoevsky, Tolstoy and Turgenev. The latter is the author of the compact novel 'Fathers and Sons' which fits well into the palette of school reading with both a small volume and a bright hero, as well as he is the author of the touching story of 'Mumu' [Boeva, 2019] which is ahead of many classical works in terms of the number of fanfictions. Among the 'irrepressible' there is not a single writer of the eighteenth century who almost completely 'dropped out' from the school literary canon. Of Pushkin's predecessors, we see only Griboyedov, who steadfastly ' has occupied his rightful place': he is not only the author of a comedy, which has become an enduring source of precedent phrases and expressions, but also the owner of a vivid biography (on this topic, the meme 'Griboyedov loved duels: he took part in duels several times a day and threw a glove in the face of everyone he met'). From the twentieth century, only the most brutal ones were 'lucky': Mayakovsky and Yesenin - of all the literary representatives of the last century, they are most often the heroes of Internet memes. Suicides and scandalous reputations 'come in handy' from their biographies (one is a hooligan, the other is a futurist and a herald), and the mass consciousness, of course, identifies poets and their lyrical heroes. However, some authors try to express themselves about the artistic and aesthetic features of their poetry, for example, accompanying the image of Mayakovsky with the caption 'One, two, three, four, seven! I have been friends with rhyme since childhood!' (Still it remains unclear whether this is an allusion to Mayakovsky's famous 'ladder', or to his sophisticated rhyme - and in what sense: positive or negative). The futurism of the early Mayakovsky is also played up: 'He offered to throw Pushkin, Dostoevsky and Tolstoy from the steamer of our time but ended up with them in the school curriculum.' As you can see, in order to become a popular hero of memes, you need both rootedness in the literary canon (i. e., first of all, in the school curriculum [Boeva, 2018]), and a vivid, amazing biography. 
It is interesting that the classic can be 'glorified' in the Runet by far from his most canonical text. So, for example, it happened with I. Brodsky whose most quoted verses in mememaking are 'Don't leave the room, / Don't make a mistake'. When, in 2020, on the eve of the poet's birthday, in St. Petersburg, graffiti with his image appeared on the wall opposite Muruzi's house, soon painted over by the housing services, the Runet reacted with a meme with the caption: 'When I tried to leave the room at least on my birthday...: ('Frequency of this quote is even ironically played in one of the memes: at the registration table there is a crowd of people with this inscription, but at the other table, with the inscription: 'Other works by Yosi', is empty. A 'sociopathic' poem inviting one to stay at home, whimsically combined cats and a photograph where he is depicted with a cat in his arms (and possibly with his famous essay 'A Room and a Half'), and caused the associative series 'Brodsky - cats - a room - home comfort - home', presented in a number of memes and strangely combined with poetics and literary reputation as an emigrant, intellectual, and Nobel Laureate. Truly, we do not know how our word will respond...

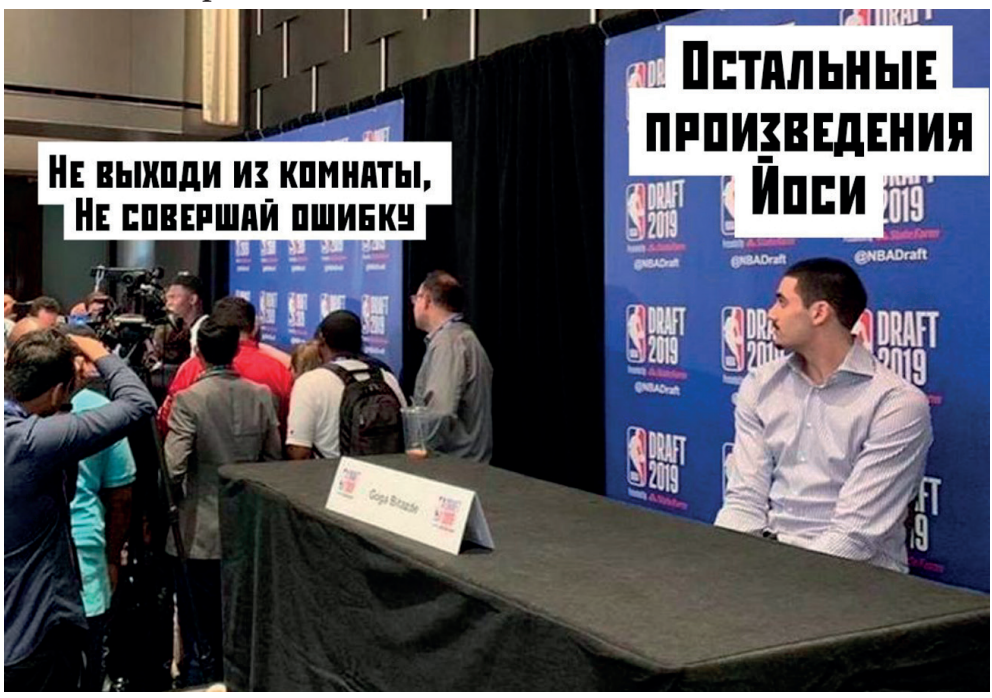

Associations with the work of writers can be very diverse - the following interesting intermedia comparison deserves attention. This music-loving story is called 'If Russian Writers Represented Genres of Music', and in six 'boxes' the following pictures are placed: 'N. Gogol: black metal, M. Lermontov: 
emocore [style of rock music which is characterized by lyricism, melody and expressiveness - GB], V. Mayakovsky: antisocial hardcore, S. Yesenin: folk rock, A. Blok: gothic metal, L. Tolstoy: neocrust / darc hardcore' [a direction in rock music in the definition of which the epithets 'hard ', 'powerful', 'atmospheric', 'melodic' are appropriate - GB]. The next meme even provoked a chat: '- Well, if you are not obsessed with rock and metal, then Gogol is rather dark ambient [a direction in electronic music, defined as gloomy and noisy - GB], Mayakovsky is rapcore [a genre in rock music using rap (recitative) as vocals - GB], Tolstoy - symphonic music. - You don't even need to compare. If Pushkin had a cue ball [apparently, slang education from the musical term 'beat' - GB], his poems would be called rap. - Who is MDM then? [Melodic death metal - a kind of extreme subgenre of metal (from the English 'melodic death metal') - GB] 'Obviously, a person who is not included in rocker culture can only superficially assess these correspondences, but similar ones can be also with painting, dance, and with architecture and other forms of art.

I will also cite as an example a plot that 'opens' Russian literature to the world and laconically, with the help of the technique of parallelism, defines the face of the writer: 'Dostoevsky kills a person; Orwell kills hope; Salinger kills youth; Kafka kills joy; Castaneda kills consciousness; Kerouac kills a generation; Polozkova kills poetry; Dontsova kills intellect; R. R. Martin kills everyone.

It seems that to the mass consciousness all the authors and heroes of their books seem to be a large friendly family whose members can easily exchange words with each other, have a drink, go to a cafe, share current difficulties... As, for example, in this meme imitating a chat with the corresponding nicknames and avatars:

'Blok: - It makes me wild that I have six volumes of works, but everyone knows only a poem about a pharmacy because it is posted on Vcontacte

Brodsky: - Zhiza ((

Mayakovsky: - It's even worse when your poems become popular only after they are sung by a famous rock group

Yesenin: - Has Bezrukov ever played you?'

Or as in this story: 'One day Pechorin, Onegin and Chatsky walk into a bar. But the bartender says to them: 'Gentlemen, please leave the place: you are superfluous men'. 


\section{Conclusion}

Of course, I have left many Internet memes using images of writers outside the scope of the conversation: they can be likened to barbaric, even vandal, statements. According to M. Berg [Berg, 2000], it is important for a barbarian to be erected over traditional sacred values, and to give his/her barbaric construction the most weighty symbolic capital. And what else can increase them if not parasitizing on names, whose position in the pantheon of the greats is legitimized by centuries of culture?

The written word is no longer omnipotent. In the post-literacy era, literature has also lost its power to affirm the status of reality, both cultural and social. Nevertheless, literature, and the figure of the writer as its personification, continues to be a powerful accumulator of cultural capital, redistributed under the new conditions of the post-literacy era.

The examples of Internet creativity that I have considered, in fact, have been created according to the same strategic principles as the poems of conceptualists and canvases of Socialist art: by appealing to iconic names and cult pre-texts, they parody and deconstruct them and allow the authors of memo opuses to assert themselves at the expense of 'intertextual victims'. However, this does not mean the overthrow of values, because the compromised artistic system (literary classics) in the process of deconstruction 'becomes a more or less positive value, if not semantic, then still functional' [Smirnov, 1994, 42].

The undertaken analysis of Internet memes confirms that the classics and classical authors, being the 'core of the cultural memory', consist of 'not the most read, but the most commented authors' [Zenkin, 2009, 282]. The discursive gap, which more and more separates those living in the era of post-literacy from the time of literary centrism, puts a person in a strange position in relation to cultural heritage and tradition: to value what has not been read, to be content with retellings and stereotypes, to entrust themselves to mythology. What are the classical authors that exist on the Runet the examples of? Tolstoy of long descriptions, Pushkin of maximum perfection, Dostoevsky of gloominess, Yesenin of hooliganism. The Runet forms a new identity which 'cannot be reduced only to the experience of a common language' [Zvereva, 2012, 14]; new cultural meanings and a new mythology, different from the mythology of the previous era, appear in it. All this testifies to anthropological changes that should become an object of observation and reflection. 


\section{References:}

1. M.M. Bahtin. Problema rechevyh zhanrov. Sobr. soch. [The problem of speech genres. Collection of works] Vol. 5. Moscow (1996), pp. 159-206.

2. Yu. V. Shchurina. Komicheskie krelizovannye teksty v internet-kommunikacii [Comic stylized texts in Internet communication]. Vestnik Novgorodskogo gosudarstvennogo universiteta [Bulletin of the Novgorod state University]. № 57 (2010), pp. 82-86.

3. E. A. Nezhura. Novye tipy kreolizovannyh tekstov v kommunikativnom prostranstve internet. Teoriya yazyka i mezhkul'turnaya kommunikaciya [New types of creolized texts in the communicative space of the Internet. Language theory and intercultural communication]. № 2 (2012), pp. 47-52.

4. S. A. Shomova. Memy kak oni est': Uchebnoe posobie [Memes as they are: A textbook]. Moscow (2018).

5. Yu. N. Karaulov. Russkij yazyk i yazykovaya lichnost' [Russian language and language personality]. Moscow (2007).

6. R. Dawkins. Egoistichnyj gen [Selfish gene.]. Moscow. (1993).

7. Yu. A. Sorokin, E. F. Tarasov. Kreolizovannye teksty i ih kommunikativnaya funkciya [Creolized texts and their communicative function]. Optimizaciya rechevogo vozdejstviya [Optimization of speech impact]. Moscow (1990), pp. 180-186.

8. Yu. V. Shchurina. Internet-memy kak fenomen internet-kommunikacii [Internet memes as a phenomenon of Internet communication]. Nauchnyj dialog [Scientific dialogue]. No3 (2012), pp. 160-172.

9. H. Jenkins. Textual Poachers: Television Fans and Participatory Culture. Routledge, New York (1992).

10. V. Zvereva. Setevye razgovory: kul'turnye kommunikacii v Runete. [Network talks: cultural communication in the Runet]. University of Bergen, Bergen (2012).

11. M.M. Bakhtin. Tvorchestvo Fransua Rable i narodnaya smekhovaya kul'tura [Creativity of Francois Rabelais and folk laughter culture]. Moscow (1990).

12. Y.M. Lotman. O russkoj literature. Stat'i i issledovaniya: istoriya russkoj prozy, teoriya literatury [About Russian literature. Articles and research: history of Russian prose, theory of literature]. St. Petersburg (1997).

13. G.S. Knabe. Dialektika povsednevnosti [Dialectics of everyday life]. Voprosy filosofii [Question of philosophy]. № 5 (1989), pp. 29-53.

14. P. Bourdieu. Pole literatury [Field of literature]. Novoe literaturnoe obozrenie [New literary review]. № 45 (2000), pp. 22-87.

15. V.B. Zemskov. Literaturnyj panteon: avtor i proizvedenie v mezhkul'turnoj kommunikacii [Literary Pantheon: author and work in intercultural communication]. 
Literaturnyj panteon: nacional'nyj i zarubezhnyj: Materialy rossijsko-francuzskogo kollokviuma. [Literary Pantheon: national and foreign: Materials of the Russian-French Colloquium]. Moscow (1999), pp. 7-19.

16. T. G. Megrelishvili. Russkij literaturnyj kanon v zerkale sovremennosti [Russian literary Canon in the mirror of modernity] Toronto Slavic Quarterly. № 44 (2013), pp. 35-48.

17. B. Dubin. Klassika, posle i ryadom: Sociologicheskie ocherki o literature i kul'ture: Sb. Statej [Classics, after and near: Sociological essays on literature and culture: Collection of articles]. Moscow (2010).

18. M. Yampolsky. Literaturnyj kanon i teoriya "sil'nogo" avtora [Literary Canon and theory of the "strong" author]. Inostrannaya literatura [Foreign literature]. № 12 (1998), pp. 214-221.

19. N. A. Guskov. I Mezhdunarodnaya nauchnaya konferenciya "Russkaya literatura v perevodah na inostrannye yazyki. Russkij literaturnyj kanon: centry i periferiya”, Krakov, 22-23 oktyabrya 2015 g. [I international scientific conference "Russian literature in translations into foreign languages. Russian literary Canon: centers and peripheries", Krakow, October 22-23, 2015]. Vestnik SPbGU. Seriya 9. Filologiya. Vostokovedenie. ZHurnalistika [Series 9. Philology. Orientalism. Journalism]. Vol 3 (2016), pp. 176-179.

20. M. Y. Berg. Literaturokratiya. Problema prisvoeniya i pereosmysleniya vlasti $\mathrm{v}$ literature [Literocracy. The problem of attribution and reinterpretation of power in literature]. Moscow (2000). https://www.litmir.me/br/?b=249049\&p=1 (Accessed 7 August 2020)

21. A. I. Reitblat. Kak Pushkin vyshel v genii: Istoriko-sociologicheskie ocherki o knizhnoj kul'ture pushkinskoj epohi [How Pushkin came out in genius: Historical and sociological essays on the book culture of the Pushkin era]. Moscow (2001).

22. C. Zenkin. Gumanitarnaya klassika: mezhdu naukoj i literaturoj [Humanitarian classics: between science and literature]. Klassika i klassiki v social'nom i gumanitarnom znanii [Classics and classics in social and humanitarian knowledge]. Moscow (2009).

23. I. N. Rozanov. Literaturnye reputacii [Literary reputations]. Moscow (1928).

24. L.F. Mashkovtseva. Istoriko-kul'turnye istoki i problemy izucheniya ponyatiya "literaturnaya reputaciya" [Historical and cultural origins and problems of studying the concept of “literary reputation”] Discussion. № 2 (20) (2012), pp. 173-174.

25. H. Blum. Zapadnyj kanon. Knigi i shkola vsekh vremen. [Western Canon. Books and school of all times] Moscow. (2017). 
26. Yu. N. Tynyanov. Poetika. Istoria literatury. Kino. [Poesis. History of Literature. Cinema]. Moscow (1977).

27. K. A. Prasolova. Slesh: problemy definicii [Slash: problems of definition]. Vestnik RGU im. Kanta. Vyp. 8. Seriya "Filologicheskie nauki" [Bulletin of the Russian state University. Kant's. Issue 8. Philological Science]. Kaliningrad (2008), pp. 100-106.

28. I. Kaspe. Klassika kak kollektivnyj opyt: literatura i teleserialy [Classics as a collective experience: literature and TV series]. Klassika i klassiki v social'nom i gumanitarnom znanii [Classics and classics in social and humanitarian knowledge]. Moscow (2009), pp. 452-489.

29. G. N. Boeva. Mozhet li Turgenev byt' ob"ektom brendinga? [Can Turgenev be the object of branding?]. Reklama i PR v Rossii: sovremennoe sostoyanie i perspektivy razvitiya: XVI Vserossijskaya nauchno-prakticheskaya konferenciya, 14 fevralya 2019 g. [Advertising and PR in Russia: current state and prospects of development: XVI all-Russian scientific and practical conference, February 14, 2019] St. Petersburg (2019), pp. 39-42.

30. G. N. Boeva. "Kanon russkoj literatury" kak kul'turnaya matrica professional'noj deyatel'nosti reklamshchikov ["Canon of Russian literature" as a cultural matrix of professional activity of advertisers]. Reklama i PR v Rossii: sovremennoe sostoyanie i perspektivy razvitiya: HV Vserossijskaya nauchno-prakticheskaya konferenciya, 15 fevralya 2018 [Advertising and PR in Russia: current state and prospects of development: XVI all-Russian scientific and practical conference, February 15, 2018]. St. Petersburg (2018), pp. 45-48.

31. I. P. Smirnov. Psihodiahronologika: Psihoistoriya russkoj literatury ot romantizma do nashih dnej. [Psychodiachronology: Psychohistory of Russian literature from romanticism To the present day]. Moscow (1994). 